\title{
VOLUME OF WOODY DETRITUS IN FRESH MAPLE-LINDEN DIBROVA IN SLOBOZHANSKYI NATIONAL NATURE PARK
}

\author{
O. Chornobrov \\ Researcher \\ Institute of Agroecology and Environmental Management of NAAS \\ (Kyiv, Ukraine) \\ e-mail: oleksandr.chornobrov@ukr.net; \\ ORCID: https://orcid.org/0000-0001-8251-1573 \\ I. Tymochko \\ Candidate of Agricultural Sciences \\ Institute of Agroecology and Environmental Management of NAAS \\ (Kyiv, Ukraine) \\ e-mail:i.tymochko@gmail.com; \\ ORCID: https://orcid.org/0000-0001-9893-3869 \\ O. Bezrodnova \\ Candidate of Biological Sciences, Associate Professor \\ V.N. Karazin Kharkiv National University \\ (Kharkiv, Ukraine) \\ e-mail: o.bezrodnova@karazin.ua; \\ ORCID: https://orcid.org/0000-0002-2506-0881
}

The article examines the volume of coarse woody detritus in fresh maple-linden-dibrova in Slobozhanskyi National Nature Park. The study was carried out in 115-year-old forest with a predominance of common oak (Quercus robur L.) of natural origin on a sample plot ( 0.24 ha) by identifying and measuring of standing and lying dead wood components. The volume of dead wood in the forest ecosystem is $32.4 \mathrm{~m}^{3} \cdot \mathrm{ha}^{-1}$ and consists of fallen (84.3\%) and standing (15.7\%). The main part of the dead wood volume is formed by one tree species - common oak (91.3\%). In general, woody detritus is characterized by I-IV stages of decomposition, at the same time detritus of III (52.5\%) and II (41.7\%) stages prevails, detritus of other decomposition stages has insignificant shares (not exceeding 5.0\%). No detritus of the last (V) stage of decomposition was detected. The volume of standing dead wood was $5.1 \mathrm{~m}^{3} \cdot \mathrm{ha}^{-1}$ and is formed by whole and broken dead trees. In terms of species composition, common oak predominates (80.4\%), other species have much smaller shares: small-leaved linden (Tilia cordata Mill.) (13.7\%) and Norway maple (Acer platanoides L.) (5.9\%). The volume of standing dead wood is dominated by detritus of decomposition stage II $\left(4.8 \mathrm{~m}^{3} \cdot \mathrm{ha}^{-1}, 94.1 \%\right)$, compared with stage I $\left(0.3 \mathrm{~m}^{3} \cdot \mathrm{ha}^{-1}, 5.9 \%\right)$. The volume of lying dead wood is $27.3 \mathrm{~m}^{3} \cdot \mathrm{ha}^{-1}$ and is formed by whole fallen trees, fragments of fallen trees (trunks) and thick branches. In terms of species composition dead wood volume is dominated by common oak detritus $\left(25.6 \mathrm{~m}^{3} \cdot \mathrm{ha}^{-1}\right.$, 93.7\%), and the shares of other species are insignificant. Fallen dead wood is represented by four stages of decomposition (I-IV). In terms of volume, decomposition stage III has an absolute advantage $\left(16.9 \mathrm{~m}^{3} \cdot \mathrm{ha}^{-1}\right.$, $61.9 \%)$, much less detritus of stage II $\left(8.7 \mathrm{~m}^{3} \cdot \mathrm{ha}^{-1}, 31.9 \%\right)$. Relatively low volume of woody detritus and the absence of dead wood of decomposition stage $V$ may be associated with forestry activities, including selective sanitary cutting and fallen woody debris removal, in the past in modern NNP areas.

Keywords: dead wood, standing dead wood, fallen dead wood, forest ecosystem, volume, decomposition stage, biodiversity conservation.

\section{INTRODUCTION}

Dead wood, or woody detritus, is an important component of forest ecosystems and performs a number of environmental and ecological functions $[1 ; 2]$. Coarse woody detritus includes standing dead and fallen trees, fragments of fallen trees (trunks), branches (fragments of branches), and thick tree roots [1]. Dead wood is a substrate and habitat for a number of living organisms, including mosses, lichens, fungi, invertebrates, as well as small birds and mammals [1-6]. According to scientists, approximately 25\% of forest biodiversity species are dependent on decomposing dead wood [7; 8]. Therefore, dead wood is an important indicator of biodiversity of forest ecosystems [4; 8]. Dead wood plays an important role in the biological cycle of substances and energy, carbon deposition, is a source of 
nutrients $[1 ; 9 ; 10]$. Assessment of dead wood as a component of forest mortmass is an unsolved problem in the context of the study of biological productivity of forests $[11 ; 12]$. Thus, the study of dead wood is an urgent problem today.

Of particular importance is the study of dead wood in natural ecosystems on protected areas, which were created for the protection, conservation and restoration of natural complexes. Slobozhanskyi National Nature Park belongs to the important protected areas of the Left-Bank Forest-Steppe of Ukraine. Its total area is 5,244 hectares [13]. Slobozhanskyi NNP is one of the important natural nuclei of the Slobozhansky-Galician ecological corridor in accordance with the program of the ecological network of Ukraine [13]. Slobozhanskyi NNP is included in the list of territories that are centers for the conservation of phytodiversity not only in Ukraine but also in Europe (Important Plant Areas of Ukraine - Bir na Merli) [14].

\section{ANALYSIS OF RECENT RESEARCH AND PUBLICATIONS}

In Ukraine in scientific publications woody detritus is considered primarily as an important component in the overall biomass of forest stands in the context of carbon deposition and the study of forest productivity $[15 ; 16]$. In the modern domestic scientific literature, some authors, in particular A. Bilous [15], consider dead wood as a component of forest mortmass - organic matter of dead woody plants, their fragments and individual dead components of living plants. Researchers A. Shvydenko and others consider that the concept of «mortass» integrally represents all components of the organic matter of dead forest plants [9].

A number of scientific papers are devoted to the study of forests mortmass in Ukraine's Polissya in the context of bioproductivity and carbon deposition. Thus, in particular, A. Bilous studied the stock of standing and fallen dead wood of softwood forests and mortmass of fallen dead wood of birch forests, U. Kotlyarevska and others - deposited carbon and energy in woody detritus of alder forests. M. Matsala and others. studied the deposited carbon in the coarse woody detritus of oak forests of Ukraine.

V. Pasternak, V. Yarotsky, V. Nazarenko, A. Garmash, M. Buksha, T. Pivovar, and others studied woody detritus in the forests of the LeftBank Forest-Steppe of Ukraine. In paper devoted to the assessment of carbon stocks and dynamics in the forests of the North-East of Ukraine [10] the authors analyzed in particular data on dead wood in the forests of Kharkiv and Sumy regions. It was found that the structure of mortmass of forest ecosystems of this region is dominated by oak, represented mainly by II-III stages of decomposition, while dead wood of other forest species has a much smaller share [10].

According to the authors [17], in the oak stands of the Left-Bank Forest-Steppe of Ukraine, the average volume of dead wood is $36.0 \mathrm{~m}^{3} \cdot \mathrm{ha}^{-1}\left(1.5-105.3 \mathrm{~m}^{3} \cdot \mathrm{ha}^{-1} 1\right)$, the average volume of standing is $15.2 \mathrm{~m}^{3} \cdot \mathrm{ha}^{-1}$, and fallen dead wood is $21.5 \mathrm{~m}^{3} \cdot \mathrm{ha}^{-1}$. On average the share of coarse woody detritus from the growing stands volume was $11.7 \%$ [17]. Scientists studied the typological structure of forests of the Volodymyrivsky nature protection research department of Slobozhanskyi National Nature Park and found that in most of the forest areas they studied, the volume of dead wood did not exceed $30 \mathrm{~m}^{3} \cdot \mathrm{ha}^{-1}$, or $8 \%$ of the growing stand volume [18].

Much less scientific papers in Ukraine is devoted to the study of dead wood as a habitat and substrate for living organisms in forest ecosystems. Abroad, numerous scientific studies have shown that the volume of woody detritus in forest ecosystems is an important indicator of biodiversity [7; 8]. The accumulation of significant volumes of dead trees increases the total surface area of dead wood in forest ecosystem, which in turn contributes to the formation of greater diversity of habitats for species of living organisms that directly or indirectly use it in their lives [5]. Therefore, a larger volume of dead wood leads to an increase in species diversity in forest ecosystems [5].

Scientists have also proven the importance of the species composition of woody detritus in the formation of habitats and substrates for a number of species dependent on it [8]. According to the authors [3], in Scandinavia, the largest number of threatened species of invertebrates, dependent on dead wood, used in their lives exclusively woody detritus of the genus oak (Quercus L.) species. It has also been found that different species of living organisms are dependent on dead wood of different tree species [3]. Only $10 \%$ of species in their lives use woody detritus of both coniferous and deciduous species [7].

An analysis of recent publications and researches has shown that dead wood stocks in the forest ecosystems of Slobozhanskyi National Park are insufficiently studied, and the scientific problem of studying the relationship between coarse woody detritus and biodiversity is unresolved.

\section{MATERIALS AND RESEARCH METHODS}

According to the physical and geographical zoning, the territory of Slobozhanskyi NNP belongs to the East Poltava Upland region of the Left Bank-Dnieper forest-steppe region of the 
Forest-steppe insufficiently moist warm zone. According to geobotanical zoning, the park is located on the extreme eastern border of Poltava district of linden-oak, pine, oak-pine forests, steppe meadows, meadow steppes and eutrophic swamps, on the extreme eastern border of the Ukrainian steppe subprovince belonging to the Eastern Europe Steppe province of oak forests, steppe meadows and meadow steppe, within the Forest-steppe subregion (zone) and the Eurasian steppe region $[19 ; 13]$.

The climate of the NNP territory belongs to the temperate-continental type. The average annual precipitation is $498-568 \mathrm{~mm}$. Approximately $65 \%(341 \mathrm{~mm})$ of total precipitation is observed in the warm period of the year (April-October). In the cold period of the year, an average of $184 \mathrm{~mm}$ of precipitation falls (35\%). Snow cover on the territory of the NNP takes place in late November - early December. The maximum snow accumulation occurs at the end of February and the depth of the snow cover reaches $14-18 \mathrm{~cm}$. The stable snow cover lasts for about 65-80 days. The territory of Slobozhanskyi NNP is characterized by unstable winds in direction and speed, but still dominated by winds of southeastern, southwestern and northwestern directions [13].

According to forest typological zoning, the territory of Slobozhanskyi NNP belongs to the Slobozhanskyi district of the fresh grud region [20]. The predominant forest types are fresh oakpine subir (38\%), fresh maple-linden dibrova $(31 \%)$ and fresh linden-oak sugrud (16\%) [13].

The study of coarse woody detritus volume was conducted in forests of natural origin, growing in fresh dibrova conditions, in the research area in the central part of the Parkhomovsky Protection Research Department (quarter 67 according to forest inventory carried out in 2010) within the regulated recreation zone [13]. In the study area, the stand is formed by common oak (Quercus robur L.), it also includes common ash (Fraxinus excelsior L.), Norway maple (Acer platanoides L.), small-leaved linden (Tilia cordata Mill.), and field maple (Acer campestre L.). Occasionally there is European white elm (Ulmus laevis Pall.).

The age of the predominant tree species common oak - is 115 years. The studied forest stand has a natural origin and has developed without significant human intervention only in the last 10 years. At the same time, before establishing this territory as Slobozhanskyi National Nature Park, forestry measures were carried out in this area, including selective sanitary cuttings and fallen dead wood removal.

The study of dead wood volume was carried out by identifying and measuring of standing and fallen deadwood components on a sample plot of 0.24 ha $(60 \mathrm{~m} \times 40 \mathrm{~m})$, established on the study site in 2020 in accordance with standardized requirements [21]. To classify the fractions and components of dead wood in general, the method developed by A. Bilous was used [15]. All dead or broken dead trees with a diameter at breast height $(1.3 \mathrm{~m})$ of $6.0 \mathrm{~cm}$ or more were included in the fraction of dead standing wood. For all components of standing dead wood the diameter and height were measured according to the methods generally accepted in forest mensuration. For standing broken dead trees up to $5 \mathrm{~m}$ in height, the trunk diameter in the middle of the height was also measured. The following components were included and accounted for in the fraction of fallen dead wood: fallen trees (trunks), fragments of fallen trees (trunks), branches (fragments of branches) with diameter in the middle of $6 \mathrm{~cm}$ and more, which were within the sample plot. For all these components of dead wood, the measurement of middle diameter and length was performed. For all components of dead wood, the species was identified by morphological characteristics. Standing and fallen dead wood was distributed according to the I-V decomposition stages according to the method [15]. The volume of whole standing dead trees (trunks) was calculated by volume tables [22]. The volume of all components of lying dead wood was calculated by Huber's formula:

$$
V=\frac{\pi}{4} d_{0.5 l}^{2} l,
$$

where $V$ - the volume of the trunk (fragment of the trunk) or a thick branch; $d_{0.5 l}$ - diameter on the trunk (fragment of the trunk) or a thick branch in the middle of the length; $l$ — the length of the trunk (fragment of the trunk) or a thick branch; $\pi-$ a constant (3.1415926...).

The volume of standing broken trees (trunks) was calculated by Huber's formula (1). Field data processing and analysis was performed using MS Excel 2016 software.

\section{RESULTS AND DISCUSSION}

The results of the study of dead wood volume by fractions and tree species are shown in table 1.

Dead wood in the studied forest stand was formed due to the tree death of five species and consist of two fractions: standing and fallen (fig. 1).

The volume of standing dead wood in stand is $5.1 \mathrm{~m}^{3} \cdot \mathrm{ha}^{-1}$ and formed by whole and broken dead trees. In terms of species composition, common oak has a significant advantage (80.4\%), small-leaved linden (13.7\%) and Norway maple $(5.9 \%)$ have much smaller shares. The total 
Volume of coarse woody detritus in fresh maple-linden dibrova in Slobozhanskyi NNP

\begin{tabular}{|c|l|c|c|c|}
\hline \multirow{2}{*}{ № } & \multirow{2}{*}{ Tree species } & \multicolumn{3}{|c|}{ Volume of dead wood, $\mathbf{~ m}^{\mathbf{3}} \cdot \mathbf{h a}^{\mathbf{- 1}}$} \\
\cline { 3 - 5 } & & standing & fallen & total \\
\hline \hline 1 & Quercus robur L. & 4.1 & 25.6 & 29.7 \\
\hline 2 & Tilia cordata Mill. & 0.7 & 0.6 & 1.3 \\
\hline 3 & Acer platanoides L. & 0.3 & 0.0 & 0.3 \\
\hline 4 & Acer campestre L. & 0.0 & 1.0 & 1.0 \\
\hline 5 & Ulmus laevis Pall. & 0.0 & 0.1 & 0.1 \\
\hline \multicolumn{2}{|l|}{ Total } & 5.1 & 27.3 & 32.4 \\
\hline
\end{tabular}

Source: performed by the authors on the basis of their own research.
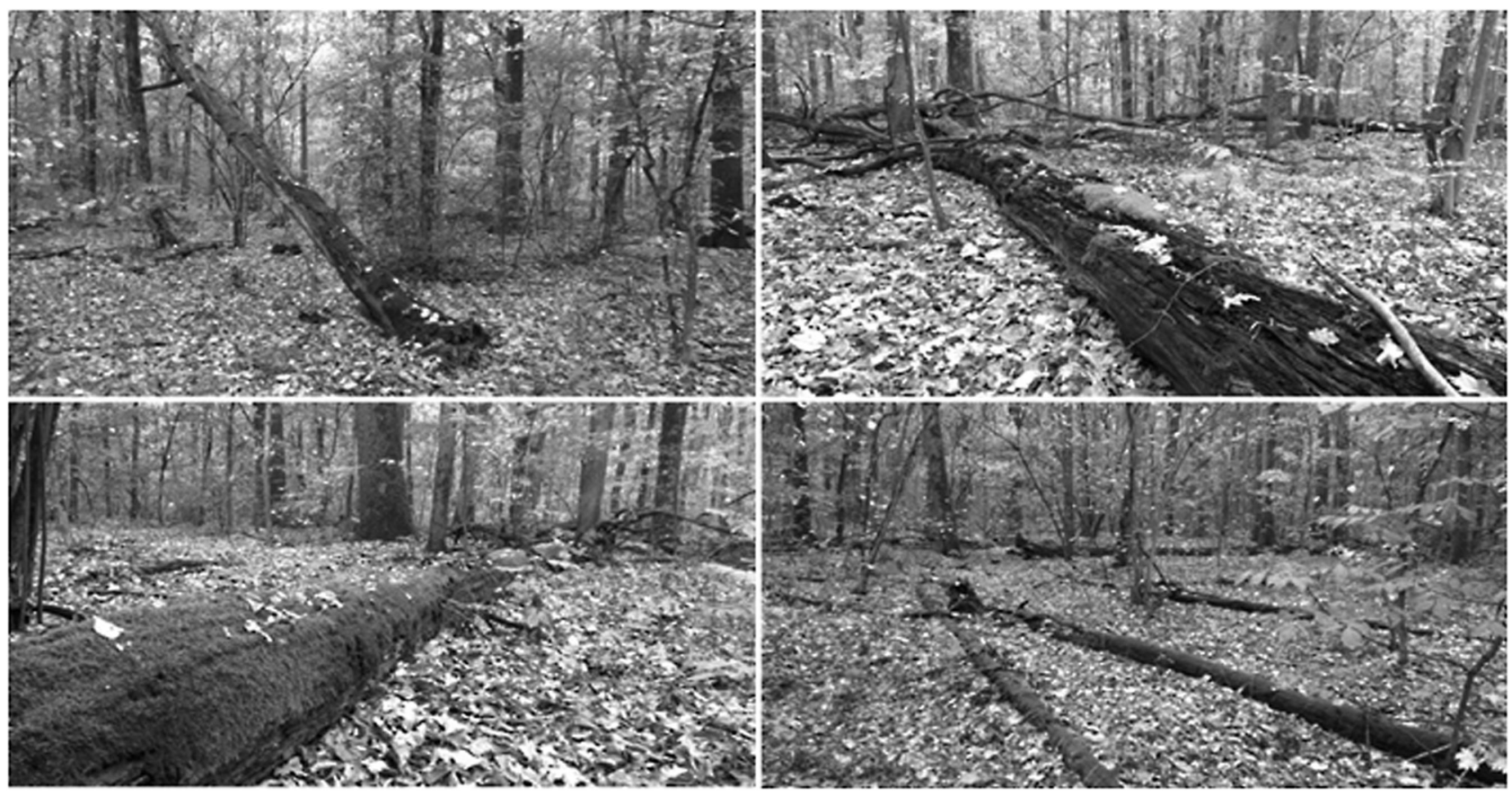

Fig. 1. Dead wood in fresh maple-linden dibrova in Slobozhanskyi NNP

Source: performed by the authors on the basis of their own research.

volume of standing dead wood is significantly dominated by detritus of decomposition stage II $\left(4.8 \mathrm{~m}^{3} \cdot \mathrm{ha}^{-1}, 94.1 \%\right)$, compared with stage I $\left(0.3 \mathrm{~m}^{3} \cdot \mathrm{ha}^{-1}, 5.9 \%\right)$. All standing dead wood of common oak and Norway maple is represented only by decomposition stage II, and small-leaved linden - only by decomposition stage I.

The volume of fallen dead wood is $27.3 \mathrm{~m}^{3} \cdot \mathrm{ha}^{-1}$, and formed due to the tree death of four species. Woody detritus of common oak $\left(25.6 \mathrm{~m}^{3} \cdot \mathrm{ha}^{-1}\right.$, $93.7 \%)$ prevails, and shares of other species - a field maple $\left(1.0 \mathrm{~m}^{3} \cdot \mathrm{ha}^{-1}, 3.7 \%\right)$, small-leaved linden $\left(0.6 \mathrm{~m}^{3} \cdot \mathrm{ha}^{-1}, 2.2 \%\right)$ and European white elm $\left(0.1 \mathrm{~m}^{3} \cdot \mathrm{ha}^{-1}, 0.4 \%\right)$ are insignificant. Fallen dead wood is formed by whole fallen trees, fragments of fallen trees (trunks) and thick branches. The average diameter of the components of woody detritus is: common oak $-6.0-30.0 \mathrm{~cm}$, field maple - 6.0-13.0 cm, small-leaved linden $8.5-12.5 \mathrm{~cm}$, European white elm - within 6.0$9.0 \mathrm{~cm}$. There was a significant moss cover on fallen oak trunks of the decomposition stages III-IV. Fragmentary moss cover also was present on the dead wood of small-leaved linden, field maple and European white elm.

In the studied forest ecosystem, fallen dead wood is represented by four stages of decomposition (I-IV), but no wood was found at the late (last) stage of decomposition (V) (Fig. 2).

In terms of volume, decomposition stage III has an absolute advantage $\left(16.9 \mathrm{~m}^{3} \cdot \mathrm{ha}^{-1}\right.$, $61.9 \%)$, much less stage II detritus $\left(8.7 \mathrm{~m}^{3} \cdot \mathrm{ha}^{-1}\right.$, 


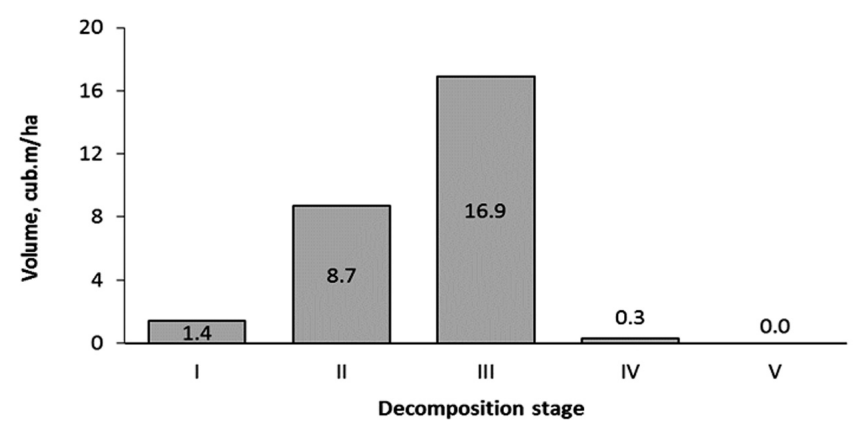

Fig. 2. Distribution of fallen dead wood volume by decomposition stages

Source: performed by the authors on the basis of their own research.

$31.9 \%$ ). Volumes and, accordingly, the share of fallen dead wood of other decomposition stages are insignificant $\left(\mathrm{I}-1.4 \mathrm{~m}^{3} \cdot \mathrm{ha}^{-1}, 5.1 \%\right.$; IV $\left.0.3 \mathrm{~m}^{3} \cdot \mathrm{ha}^{-1}, 1.1 \%\right)$.

Fallen oak dead wood is represented by four stages of decomposition, among which III (61.9\%) and II (32.0\%) stages prevail. A much smaller share is stage I detritus (5.3\%), and the share of stage IV is insignificant (0.8\%) (Fig. 3).

Fallen dead wood of field maple and smallleaved linden is characterized by the predominance of decomposition stage III. For example, field maple dead wood is formed by II-IV decomposition stages, but stage III has an absolute advantage (66.2\%). For small-leaved linden, the share of wood in this stage of decomposition is $85.1 \%$. At the same time, elm detritus is characterized by only one decomposition stage II.

The total dead wood volume in the studied maple-linden dibrova is $32.4 \mathrm{~m}^{3} \cdot \mathrm{ha}^{-1}$. It was formed as a result of trees death of five tree species: common oak, small-leaved linden, field maple, Norway maple and European white elm. Dead wood volume is dominated by fallen dead wood - 84.3\%, and the share of standing, respectively, is $15.7 \%$. The main part of the dead wood volume is formed by only one tree species - common oak, the share of its detritus is $91.7 \%$. The other four tree species formed only $8.3 \%$ of the detritus volume, respectively (Fig. 4).

Common oak, field maple and elm are characterized by the predominance of fallen dead wood, while other tree species are characterized by standing. Only for two tree species common oak and small-leaved linden there is woody detritus of both fractions (Fig. 5).

For common oak, the structure of woody detritus volume by fractions is as follows: standing - $13.9 \%$, fallen dead wood $-86.1 \%$. In general, in the studied forest ecosystem, woody detritus is characterized by I-IV decomposition stages, at the same time detritus of stages III $(52.5 \%)$ and II $(41.7 \%)$ has a significant advantage, detritus of other decomposition stages has insignificant shares ( $-5,0 \%$; IV $-0.8 \%)$.

Our results were compared with the data of studies of coarse woody detritus in forest ecosystems of Ukraine. According to the report «The state of Europe's forests» (2015) [23], the average volume of dead wood in the forests of Ukraine is estimated at $6.0 \mathrm{~m}^{3} \cdot \mathrm{ha}^{-1}$ (standing $-3.7 \mathrm{~m}^{3} \cdot \mathrm{ha}^{-1}$, fallen $\left.-2.3 \mathrm{~m}^{3} \cdot \mathrm{ha}^{-1}\right)$.

V. Pasternak and others found that the average dead wood volume in the forests of the North-East of Ukraine is $10.4 \mathrm{~m}^{3} \cdot \mathrm{ha}^{-1}(0-$ $\left.84.9 \mathrm{~m}^{3} \cdot \mathrm{ha}^{-1}\right)$, and the highest values were observed in areas with protected status [10]. According to the authors [17], in the oak stands of the Left-Bank Forest-Steppe of Ukraine, the average volume of dead wood is $36.0 \mathrm{~m}^{3} \cdot \mathrm{ha}^{-1}$ $\left(1.5-105.3 \mathrm{~m}^{3} \cdot \mathrm{ha}^{-1}\right)$. The share of coarse woody detritus from growing stock volume on average was $11.7 \%$ [17].

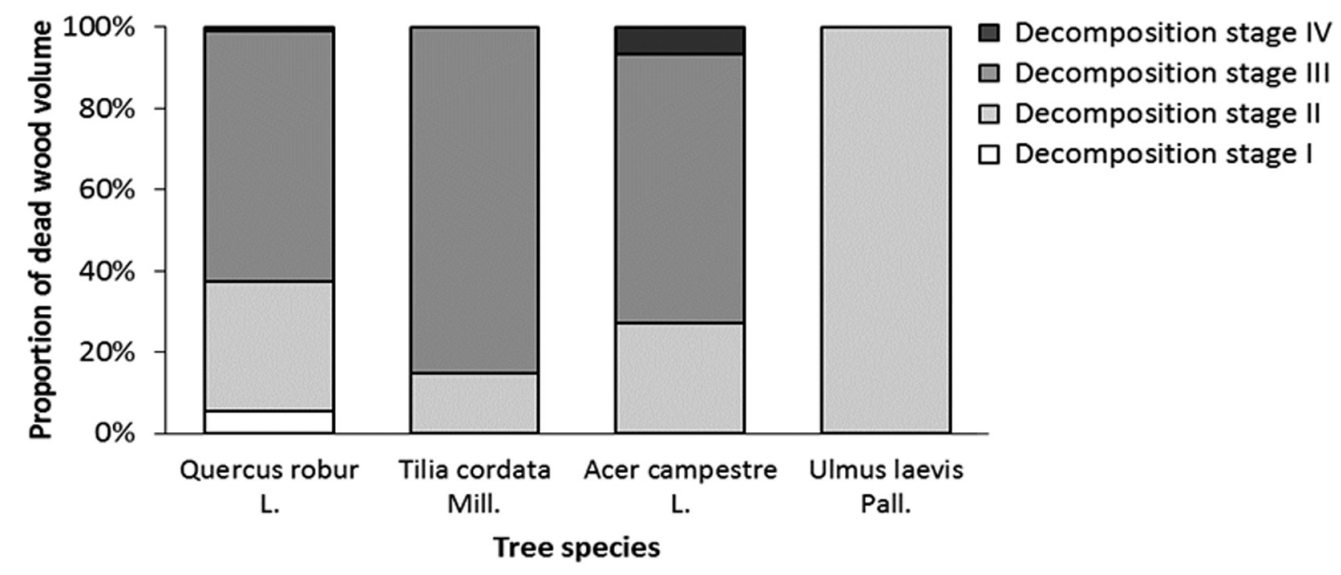

Fig. 3. Distribution of fallen dead wood volume by tree species and decomposition stages Source: performed by the authors on the basis of their own research. 


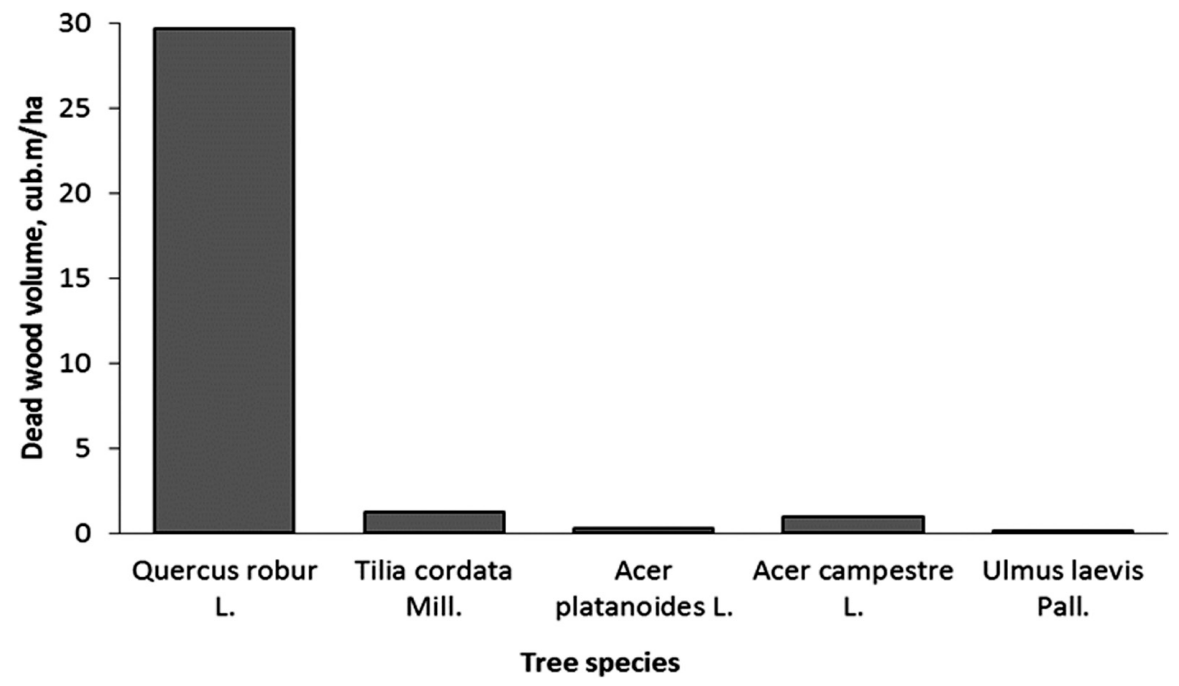

Fig. 4. Distribution of the total dead wood volume by tree species.

Source: performed by the authors on the basis of their own research.

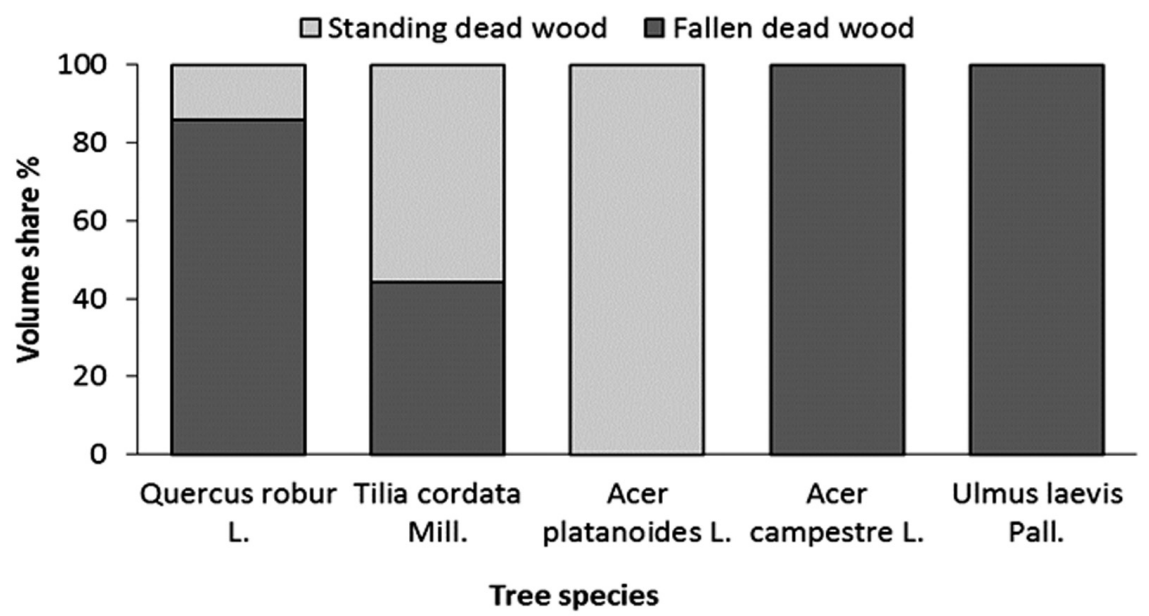

Fig. 5. Distribution of the total dead wood volume (\%) by fractions and tree species. Source: performed by the authors on the basis of their own research.

According to the authors, who estimated the stocks of woody detritus in the forests of Slobozhanskyi NNP according to state forest inventory data [24], the average volume of coarse woody detritus was generally equal to $9.1 \mathrm{~m}^{3} \cdot \mathrm{ha}^{-1}$, for maple-linden dibrova $-8.8 \mathrm{~m}^{3} \cdot \mathrm{ha}^{-1}$.

Our data on dead wood volume in the forests of Slobozhanskyi NNP are generally consistent with the results of similar studies. The considerable exceeding of our results compared with the data of scientific paper [24], can be explained by the fact that the authors in this paper used data of forest inventory conducted in 2010, and we studied woody detritus on a sample plot established in 2020. In addition, it should be taken into account that only a part of dead wood available in the forest plot can be detected during forest inventory.
At the same time, the data we have obtained on woody detritus volume are generally low compared to the data of other protected areas, where the biodiversity conservation is a priority. According to the authors [25], in forests dominated by oak (Quercus sp.) in Nature Reserve in Austria, the average volume of coarse woody detritus was $107.3 \mathrm{~m}^{3} \cdot \mathrm{ha}^{-1}$, the share of standing wood $-22 \%$, fallen dead wood $-78 \%$. In the natural lindenash-oak forests of the Holosiivskyi National $\mathrm{Na}-$ ture Park (Kyiv) within the strict protection zone the volume of dead wood is $94.2 \mathrm{~m}^{3} \cdot \mathrm{ha}^{-1}$, the share of standing dead wood is $25.4 \%$, fallen dead wood is $74.6 \%$ [26].

Stocks of dead wood in forest ecosystems depend on climatic conditions, the trophic and moisture site conditions, species composition of the stand, natural disturbances in the region 
(windthrows, windbreaks, fires etc.) and the impact of biotic factors (insects, diseases etc.) $[27 ; 9]$. An important factor that negatively affects the accumulation of dead wood in forests is forestry, as during sanitary cuttings and tending measures, dead standing, damaged and fallen trees are usually removed from forest stands.

Another factor affecting woody detritus stocks may be the length of time that has elapsed since the declaration of the protected area and the establishment of a strict protection regime. The forests in the above-mentioned Lange-Leitn Nature Reserve in Austria have not been significantly affected by human since 1935 [25]. Natural forests in the Vita River valley within the Holosiivskyi National Nature Park have been developing naturally without human intervention for the last 30 years [26]. The forest stands we study have been developing without human intervention for the last 10 years. In the past some forestry activities, including selective sanitary cuttings and the fallen dead wood removal were carried out in these forests, which could be an important factor of relatively low volume of woody detritus.

\section{CONCLUSIONS}

The volume of coarse woody detritus in the fresh maple-linden dibrova in Slobozhanskyi National Nature Park is $32.4 \mathrm{~m}^{3} \cdot \mathrm{ha}^{-1}$ which is formed by five tree species, consists of two fractions (standing and fallen) and is characterized by four decomposition stages. Relatively low dead wood volume and lack of decomposition stage $\mathrm{V}$ detritus are explained by: forestry activities in the studied forest stands in the past, short protection period of this area, and lack of natural disturbances that could lead to considerable deadwood stocks. An important feature of the studied forest ecosystem is the significant share of detritus of decomposition stage III in volume of fallen dead wood. Considering that an important aspect of management of protected areas ecosystems is biodiversity conservation, further measures in Slobozhanskyi NNP should be aimed at ensuring sufficient stocks of dead wood and the diversity of its components by species composition and decomposition stages.

\section{REFERENCES}

1. Harmon, M.E. et al. (1986). Ecology of coarse woody debris in temperate ecosystems. Advances in ecological Research, 15, 133-302. DOI: https://doi.org/10.1016/S0065-2504(03)34002-4 [in English].

2. Stevens V. The ecological role of coarse woody debris: an overview of the ecological importance of CWD in B.C. forests. Res. Br., B.C. Min. For., Victoria, B.C., Work. 30: 26. 1997 [in English].

3. Jonsell, M., Weslien, J., \& Ehnstrom, B. (1998). Substrate requirements of red-listed saproxylic invertebrates in Sweden. Biodiversity and Conservation, 7, 749-764. DOI: https://doi.org/10.1023/ A:1008888319031[in English].

4. Humphrey, J.W., Sippola, A.L., Lemperiere, G., Dodelin, B., Alexander, K.N.A. \& Butler, J.E. (2004). Deadwood as an indicator of biodiversity in European forests: from theory to operational guidance. EFI-Proceedings, 51, 193-206 [in English].

5. Müller, J \& Bütler, R. (2010). A review of habitat thresholds for dead wood: A baseline for management recommendations in European forests. European Journal of Forest Research, 129, 981-992. DOI: 10.1007/s10342-010-0400-5 [in English].

6. Priadko, O.I., Chornobrov, O.Yu., Datsiuk, V.V., Virchenko, V.M., Zykova, M.O., Andriievska, O.L. (2019). Do bioriznomanittia dubovo-yasenevykh lisiv dolyny $r$. Vita ta yoho roli u rozkladanni vidmerloi derevyny na terytorii NPP «Holosiivskyi» [Concerning biodiversity of oak-ash forests in Vita River valley and its role in decomposition of dead wood in «Holosiivskyi» NNP]. Functioning protected areas in modern conditions' 19: Materialy mizhnarodnoi naukovo-praktychnoi konferentsii (Synevyr, 18-20 veresnia 2019 r.) - Proceedings of the International Scientific and Practical Conference (pp. 77-82) [in Ukrainian].

7. Stokland, J.N., Tomter, S.M., \& Soderberg, U. (2004). Development of Dead Wood Indicators for Biodiversity Monitoring: Experiences from Scandinavia. EFI Proceedings, 51, 207-226 [in English].

8. Schuck, A., Meyer, P., Menke, N., Lier, M. \& Lindner, M. (2004). Forest biodiversity indicator: dead wood a proposed approach towards operationalising the MCPFE indicator. EFI-Proceedings, 51, 49-77 [in English].

9. Shvidenko, A.Z., Shhepashhenko, D.G. \& Nil'sson, S. (2009). Ocenka zapasov drevesnogo detrita v lesah Rossii. [Assessment of woody detritus in forests of Russia]. Lesnaja taksacija i lesoustrojstvo - Forest mensuration and inventory, 1 (41), 133-147 [in Russian].

10. Pasternak, V. P., Yarotskyi, V.Yu. (2013). Zapasy ta dynamika vidmerloi derevyny u lisakh pivnichnoho skhodu Ukrainy [Stocks and dynamics of dead wood in the forests of northeastern Ukraine]. Naukovyi visnyk NUBiP Ukrainy - Scientific Bulletin of NULES of Ukraine, 152, 2, 93-100 [in Ukrainian].

11. Lakyda, P.I., Bilous, A.M., Vasylyshyn, R.D., Makarchuk, I.Ya. (2012). Bioproduktyvnist ta enerhetychnyi potentsial miakolystianykh derevostaniv Ukrainskoho Polissia [Bioproductivity and energy potential of 
softwood stands of Ukrainian Polissya]. Korsun-Shevchenkivskyi: FOP V.M. Havryshenko [in Ukrainian].

12. Pasternak, V.P. (2011). Bioproduktyvnist lisiv pivnichnoho skhodu Ukrainy v konteksti zmin klimatu [Bioproductivity of forests of northeastern Ukraine in the context of climate change]. Extended abstract of Doctor's thesis. Kyiv [in Ukrainian].

13. Research Institution «Ukrainian Research Institute of Environmental Problems» (UKRNDIEP) (2015). Proekt orhanizatsii terytorii natsionalnoho pryrodnoho parku «Slobozhanskyi», okhorony, vidtvorennia ta rekreatsiinoho vykorystannia yoho pryrodnykh kompleksiv i obiektiv [The project of territorial organization of Slobozhanskyi National Nature Park, protection, restoration and recreational use of its natural complexes and objects]. Kharkiv [in Ukrainian].

14. Bezrodnova, O.V., Saidakhmedova, N.B. (2017). Bir na Merli / Important Plant Areas of Ukraine. Ed. Onyshchenko, V.A. Kyiv: Alterpress, 42-44 [in English].

15. Bilous, A.M. (2014). Metodyka doslidzhennia mortmasy lisiv [Methodology of the research mortmass of forest]. Bioresursy i pryrodokorystuvannia - Biological Resources and Nature Management, 6, 3-4, 134-145 [in Ukrainian].

16. Volodymyrenko, V. M., Kotliarevska, U.M., Surai, V.A., Klochko, V.M. (2016). Mortmasa lisovykh ekosystem u suchasnomu ekoresursnomu vymiri [Mortmass of forest ecosystems in the modern eco-resource dimension]. Naukovyi visnyk NLTU Ukrainy - Scientific Bulletin of UNFU, 26.5, 188-194 [in Ukrainian].

17. Yarotskiy, V.Yu., Pasternak, V.P. \& Nazarenko, V.V. (2019). Deadwood in the oak forests of the Left Bank Forest-steppe of Ukraine. Folia Forestalia Polonica, 61(4), 247-254. DOI: https://doi.org/10.2478/ ffp-2019-0024 [in English].

18. Pasternak, V.P., Yarotskyi, V.Yu. \& Harmash, A.V. (2017). Typolohichne riznomanittia lisiv Volodymyrivskoho pryrodookhoronnoho naukovo-doslidnoho viddilennia NPP «Slobozhanskyi» [Forest typological diversity of Volodymyrivske nature protection research department of Slobozhanskiy NNP]. The Journal of V.N.Karazin Kharkiv National University. Series «Biology», 28, 169-174. DOI: https://doi. org/10.26565/2075-5457-2017-28-22 [in Ukrainian].

19. Rudenko, L. G. (Ed.). (2008). Nacional'nyj atlas Ukrai'ny [National atlas of Ukraine]. Kyiv: DNVP «Kartografija». [in Ukrainian].

20. Ostapenko, B.F., Tkach, V.P. (2002). Lisova typolohiia [Forest typology]. Kharkiv: Vyd-vo Kharkivs. derzh. ahrarnoho universytetu im. V.V. Dokuchaieva [in Ukrainian].

21. Ploshchi probni lisovporyadni. Metod zakladannya. [Forest inventory sample plots. Establishing method]. (2006). Corporate standard 02.02-37-476:2006]. 2007. Valid from May 1, 2007. Kyiv: Minahropolityky Ukrainy [in Ukrainian].

22. Kashpor, S.M. \& Strochynskyi, A.A. (Eds.). (2013). Lisotaksatsiinyi dovidnyk [Forest taxation handbook]. Kyiv: Vyd. dim «Vinichenko» [in Ukrainian].

23. State of Europe's Forests 2015 Report. Forest Europe [Electronic source] URL: https://www.foresteurope.org/docs/fullsoef2015.pdf

24. Furdychko, O.I., Chornobrov, O.Yu., Solomakha, I.V., Tymochko I.Ya. (2021). Otsiniuvannia zapasiv hruboho derevnoho detrytu u lisovykh ekosystemakh natsionalnoho pryrodnoho parku «Slobozhanskyi» [Estimation of coarse woody debris stocks in forest ecosystems of Slobozhansky National Nature Park. Naukovi dopovidi NUBiP Ukrainy. Biolohiia, biotekhnolohiia, ekolohiia - Scientific reports of NULES of Ukraine. Biology, biotechnology, ecology, 1 (89), DOI: https://doi.org/10.31548/dopovidi2021.01.003 [in Ukrainian].

25. Rahman, M., Frank, G., Ruprecht, H. \& Vacik, H. (2008). Structure of coarse woody debris in LangeLeitn Natural Forest Reserve, Austria. Journal of forest science, 54 (4), 161-169. DOI: https://doi. org/10.17221/3102-JFS [in English].

26. Chornobrov, O.Yu. Sotnyk, L.P., Khodyn, O.B., Konishchuk, V.V., Tymochko, I.Ya., Solomakha, I.V. (2020). Ekolohichna otsinka zapasu mertvoi derevyny u pryrodnykh lystianykh lisakh dolyny r. Vity u natsionalnomu pryrodnomu parku «Holosiivskyi» [Ecological assessment of dead wood volume in natural deciduous forests in Vita river valley in Holosiivskyi National Nature Park]. Ahroekolohichnyi zhurnal - Agroecological journal, 2, 45-54. DOI: https://doi.org/10.33730/2077-4893.2.2020.207680 [in Ukrainian].

27. Hahn, K. \& Christensen M. (2004). Dead wood in European forest reserves — a reference for forest management. EFI Proceedings, 51, 181-191 [in English]. 


\title{
ЗАПАС ДЕРЕВНОГО ДЕТРИТУ У СВІЖКЙ КЛЕНОВО-ЛИПОВІЙ ДІБРОВІ НАЦІОНАЛЬНОГО ПРИРОДНОГО ПАРКУ «СЛОБОЖАНСЬКИЙ»
}

\author{
О.Ю. Чорнобров \\ науковий співробітник \\ Інститут агроекології і природокористування НАAН (м. Київ, Україна) \\ e-mail: oleksandr.chornobrov@ukr.net; \\ ORCID: https://orcid.org/0000-0001-8251-1573 \\ I.Я. Тимочкокандидат сільськогосподарських наук, докторант \\ Інститут агроекології і природокористування НAAH (м. Київ, Україна) \\ e-mail: i.tymochko@gmail.com; \\ ORCID: https://orcid.org/0000-0001-9893-3869 \\ О.В. Безроднова \\ кандидат біологічних наук, доцент \\ Харківський національний університет імені В.Н. Каразіна \\ (м. Харків, Україна) \\ e-mail: o.bezrodnova@karazin.ua; \\ ORCID: https://orcid.org/0000-0002-2506-0881
}

У статті досліджено запаси грубого деревного детриту у свіжій кленово-липовій діброві в національному природному парку "Слобожансъкий». Вивчення мертвої деревини здійснювалосъ y 115-річних лісових насадженнях із домінуванням дуба звичайного (Quercus robur L.) природного походження на пробній площі (0,24 га) методом сущільного обліку. Установлено, що запас деревного детриту в лісовій екосистемі становить $32,4 \mathrm{~m}^{3} \cdot 2 a^{-1}$ та складається з лежачої мертвої деревини $(84,3 \%)$ та сухостою (15,7\%). Основна частина запасу мертвої деревини утворена одним деревним видом - дубом звичайним (91,3\%). Загалом деревний детрит характеризується I-IV класами деструкиї̈, водночас значну перевагу має детрит III (52,5\%) і II (41,7\%) класів розкладання, детрит інших класів розкладання має незначні частки (не перевищують 5,0\%). Не було виявлено детриту останнъого (V) класу деструкиї̈. Сухостійна мертва деревина має запас 5,1 $\mathrm{m}^{3} \cdot \mathrm{ra}^{-1}$ та утворена иілими та зламаними сухостійними деревами. За породним складом значну перевагу має дуб звичайний (80,4\%), значно менші частки мають липа дрібнолиста (Tilia cordata Mill.) (13,7\%) ma клен гостролистий (Acer platanoides L.) (5,9\%). У загальному запасі сухостою значно переважає деревина II класу деструкиії $\left(4,8 \mathrm{~m}^{3} \cdot 2 a^{-1}, 94,1 \%\right)$, порівнюючи з I класом $\left(0,3 \mathrm{~m}^{3} \cdot 2 a^{-1}, 5,9 \%\right)$. Лежача мертва деревина має запас $27,3 \mathrm{~m}^{3} \cdot 2 \mathrm{a}^{-1}$ та утворена иілими поваленими деревами, фбрагментами повалених дерев (стовбурів) та грубими гілками. За породним складом переважає деревний детрит

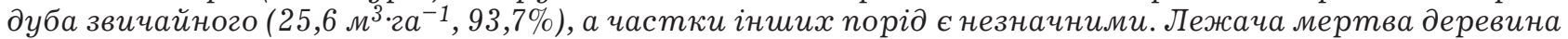
представлена чотирма класами деструкиї (I-IV). За запасом абсолютну перевагу має III клас деструкиї (16,9 $\left.\mathrm{m}^{3} \cdot 2 a^{-1}, 61,9 \%\right)$, значно менше детриту II класу $\left(8,7 \mathrm{~m}^{3} \cdot 2 \mathrm{a}^{-1}, 31,9 \%\right)$. Порівняно невисокі запаси деревного детриту та відсутність відмерлої деревини $V$ класу деструкиї̈ може бути пов'язане з проведенням лісогосподарсъких заходів, зокрема вибіркових санітарних рубок та ліквідацї захаращеності, у минулому на територіях сучасного НПП.

Ключові слова: мертва деревина, сухостій, лежача відмерла деревина, лісова екосистема, запас, клас деструкиї̈, збереження біорізноманіття.

\section{ЛITEРАТУРА}

1. Harmon M.E. et al. Ecology of coarse woody debris in temperate ecosystems. Advances in ecological Research. 1986. No 15. P. 133-302. DOI: https://doi.org/10.1016/S0065-2504(03)34002-4

2. Stevens V. The ecological role of coarse woody debris: an overview of the ecological importance of CWD in B.C. forests. Res. Br., B.C. Min. For., Victoria, B.C., Work. 30: 26. 1997.

3. Jonsell M., Weslien J., Ehnstrom B. Substrate requirements of red-listed saproxylic invertebrates in Sweden. Biodiversity and Conservation. 1998. Vol. 7. P. 749-764. DOI: https://doi.org/10.1023/ A:1008888319031

4. Humphrey J.W. et al. Deadwood as an indicator of biodiversity in European forests: from theory to operational guidance. EFI-Proceedings. 2004. Vol. 51. P. 193-206.

5. Müller, J \& Bütler, R. A review of habitat thresholds for dead wood: A baseline for management recommendations in European forests. European Journal of Forest Research. 2010. Vol. 129. P. 981-992. DOI: $10.1007 / \mathrm{s} 10342-010-0400-5$.

6. Прядко О.І. та ін. До біорізноманіття дубово-ясеневих лісів долини р. Віта та його ролі у розкладанні відмерлої деревини на території НПП «Голосіївський». Функиіонування природоохоронних територій в сучасних умовах: матеріали міжнародної науково-практичної конференції з нагоди 30-річчя національного природного парку «Синевир» (Синевир, 18-20 вересня 2019 р.). Синевир, 2019. C. $77-82$. 
7. Stokland J.N., Tomter S.M., Soderberg U. Development of Dead Wood Indicators for Biodiversity Monitoring: Experiences from Scandinavia. EFI-Proceedings. 2004. Vol. 51. P. 207-228.

8. Schuck, A., Meyer, P., Menke, N., Lier, M. and Lindner, M. Forest biodiversity indicator: dead wood a proposed approach towards operationalising the MCPFE indicator. EFI-Proceedings. 2004. Vol. 51. P. 49-77.

9. Швиденко А.З., Щепащенко Д.Г., Нильссон С. Оценка запасов древесного детрита в лесах России. Лесная таксация и лесоустройство. 2009. Вып. 1 (41). Сибирь: СГТУ, 2009. С. 133-147.

10. Пастернак В.П., Яроцъкий В.Ю. Оиінювання запасів і динаміка вуглецю у лісах Північного сходу України. Науковий вісник НЛту України. 2013. Вип. 23.6. С. 57-62.

11. Лакида П.І., Білоус А.М., Василишин Р.Д., Макарчук І.Я. Біопродуктивність та енергетичний потенціал м'яколистяних деревостанів Українського Полісся: моногр. Корсунь-Шевченківський: ФОП B.М. Гавришенко, 2012. 454 с.

12. Пастернак В.П. Біопродуктивність лісів північного сходу України в контексті змін клімату: автореф. дис. ... д-ра с.-г. наук: 06.03.02, 06.03.03. Київ, 2011. 41 с.

13. Проект організації території національного природного парку «Слобожанський», охорони, відтворення та рекреаційного використання його природних комплексів і об'єктів / Затверджено наказом Мінприроди України від 10.01.2018 № 4. Харків, 2015. 687 с.

14. Bezrodnova O.V., Saidakhmedova N.B. Bir na Merli. Important Plant Areas of Ukraine / Ed. V.A. Onyshchenko. Kyiv: Alterpress, 2017. P. 42-44.

15. Білоус А.М. Методика дослідження мортмаси лісів. Біоресурси $i$ природокористування. 2014. Т. 6. № 3-4. С. $134-145$.

16. Володимиренко В. М., Котляревська У.М., Сурай В.А., Клочко В.М. Мортмаса лісових екосистем у сучасному екоресурсному вимірі. Науковий вісник НЛтУ Украӥни. 2016. Вип. 26.5. С. 188-194.

17. Yarotskiy V.Yu., Pasternak V.P., Nazarenko V.V. Deadwood in the oak forests of the Left Bank Foreststeppe of Ukraine. Folia Forestalia Polonica. 2019. No 61 (4). P. 247-254. DOI: https://doi.org/10.2478/ ffp-2019-0024

18. Пастернак В.П., Яроцький В.Ю., Гармаш А.В. Типологічне різноманіття лісів Володимирівського природоохоронного науково-дослідного відділення НПП «Слобожанський». Вісник Харківсъкого національного університету імені В.Н. Каразіна. Серія "Біологія». 2017. Вип. 28. С. 169-174. DOI: https://doi.org/10.26565/2075-5457-2017-28-22

19. Національний атлас України / за ред. Л.Г. Руденко. Київ: ДНВП «Картографія», 2008.440 с.

20. Остапенко Б.Ф., Ткач В.П. Лісова типологія. Харків: Вид-во Харківс. держ. аграрного університету ім. В.В. Докучаєва, 2002. 204 с.

21. Площі пробні лісовпорядні. Метод закладання: СОУ 02.02-37-476:2006. [Чинний від 2007-05-01]. Київ: Мінагрополітики України, 2006. 32 с.

22. Лісотаксаційний довідник / Затверджено Державним агентством лісових ресурсів України; за ред. C.M. Кашпора, А.А. Строчинського. Київ: Вид. дім «Вініченко», 2013. 496 с.

23. State of Europe's Forests 2015 Report. Forest Europe. URL: https://www.foresteurope.org/docs/ fullsoef2015.pdf

24. Фурдичко О.І. та ін. Оцінювання запасів грубого деревного детриту у лісових екосистемах національного природного парку «Слобожанський». Наукові доповіді НУБіП України. Біологія, біотехнологія, екологія. 2021. № 1 (89) DOI: https://doi.org/10.31548/dopovidi2021.01.003

25. Rahman M., Frank G., Ruprecht H. and Vacik H. Structure of coarse woody debris in Lange-Leitn Natural Forest Reserve, Austria. Journal of forest science. 2008. 54 (4). P. 161-169. DOI: https://doi. org/10.17221/3102-JFS

26. Чорнобров О.Ю. та ін. Екологічна оцінка запасу мертвої деревини у природних листяних лісах долини р. Віти у національному природному парку «Голосіївський». Агроекологічний журнал. 2020. № 2. C.45-54. DOI: https://doi.org/10.33730/2077-4893.2.2020.207680

27. Hahn K., Christensen M. Dead wood in European forest reserves - a reference for forest management. EFI Proceedings. 2004. No 51. P. 181-191.

\section{ВІДОМОСТІ ПРО АВТОРІВ}

Чорнобров Олександр Юрійович, науковий співробітник, Інститут агроекології і природокористування НААН (вул. Метрологічна, 12, м. Київ, Україна, 03143; e-mail: oleksandr. chornobrov@ukr.net; тел.: +380969277701; ORCID: https://orcid.org/0000-0001-8251-1573)

Тимочко Ігор Ярославович, кандидат сільськогосподарських наук, докторант, Інститут агроекології і природокористування НАAН (вул. Метрологічна, 12, м. Київ, Україна, 03143; e-mail: i.tymochko@gmail.com; тел.: +380673432615; ORCID: https://orcid.org/0000-0001-9893-386)

Безроднова Ольга Володимирівна, кандидат біологічних наук, доцент, Харківський національний університет імені В.Н. Каразіна (майдан Свободи, 4, Харків, Україна, 61022; e-mail: o.bezrodnova@karazin.ua; тел.: +380501960118; ORCID: https://orcid.org/0000-0002-2506-0881) 